\title{
Clay and Refractory Materials Slurries in Inductively Coupled Plasma Optical Emission Spectrometry: Effects of Mechanochemical Synthesis on Emission Intensities of Analytes
}

\author{
Mirian C. Santos ${ }^{a}$, Ana Rita A. Nogueira ${ }^{b}$ and Joaquim A. Nóbrega ${ }^{*, a}$ \\ ${ }^{a}$ Departamento de Química, Universidade Federal de São Carlos, CP 676, 13560-970 São Carlos - SP, Brazil \\ ${ }^{b}$ Embrapa Pecuária Sudeste, São Carlos - SP, Brazil
}

\begin{abstract}
Neste trabalho foi investigada a aplicação da síntese mecanoquímica para promover reações na amostra e sintetizar novos compostos visando aumentar as intensidades de emissão de elementos presentes em suspensões de argilas e materiais refratários quando introduzidas em espectrômetro de emissão óptica com plasma acoplado indutivamente com configuração axial. A hipótese formulada é que é possível gerar compostos mais voláteis durante a moagem e esses novos compostos causam aumento da intensidade dos sinais de emissão para os analitos em suspensões introduzidas no plasma. A ação de dois modificadores, $\mathrm{LiBO}_{2} \mathrm{e} \mathrm{Na}_{2} \mathrm{CO}_{3}$, adicionados durante a etapa de moagem foi investigada. As argilas e materiais refratários foram moídos juntamente com os modificadores químicos durante 2 $\mathrm{h}$ usando um moinho de bolas de alto impacto com recipiente e bolas de carbeto de tungstênio. As suspensões foram preparadas dispersando as argilas e os materiais refratários modificados em solução $10 \% \mathrm{v} \mathrm{v}^{-1} \mathrm{HNO}_{3}$ e, posteriormente, sonicadas em banho de ultra-som para melhorar a homogeneização. Os compostos produzidos durante a etapa de moagem foram caracterizados por difração de raios $\mathrm{X}$ e análise termogravimétrica. Ambas as técnicas indicaram a formação de novos compostos nas argilas e materiais refratários por síntese mecanoquímica. Os efeitos da modificação química foram avaliados pelas mudanças nas intensidades de emissão dos analitos $\mathrm{Al}, \mathrm{Ca}, \mathrm{Fe}, \mathrm{K}, \mathrm{Mg}$, P, Si e Ti. Ambos modificadores causaram aumento na sensibilidade para todos os analitos de até $665 \%\left(\mathrm{Na}_{2} \mathrm{CO}_{3}\right)$ e $583 \%\left(\mathrm{LiBO}_{2}\right)$ quando comparados às intensidades dos sinais de emissão obtidos para os analitos nas suspensões preparadas com as amostras sem modificação química.
\end{abstract}

The developed work investigated the application of mechanochemical synthesis for promoting reactions in the samples and for synthesizing new compounds for increment of emission intensities of analytes in clays and refractory materials slurries in inductively coupled plasma optical emission spectrometry with axial viewing. The hypothesis is that it is possible to generate more volatile compounds during the grinding step and these new compounds will increase the intensities of emission signals for slurries introduced in the plasma. The action of two chemical modifiers, $\mathrm{LiBO}_{2}$ and $\mathrm{Na}_{2} \mathrm{CO}_{3}$, added during the grinding step was evaluated. The clays and refractory materials mixed with the chemical modifier were ground for $2 \mathrm{~h}$ using a high impact ball mill with a tungsten carbide grinding container and balls. Slurries were prepared by dispersing the modified clays and refractory materials in $10 \% \mathrm{v} \mathrm{v}^{-1}$ $\mathrm{HNO}_{3}$ solution and by shaking them in an ultrasonic bath to ensure good dispersion. The compounds produced during the grinding step were characterised by X-ray diffraction and thermogravimetric analysis. Both techniques indicated the formation of new compounds in clays and refractory materials by mechanochemical synthesis. Chemical modification effects were evaluated by changes of the emission intensities of $\mathrm{Al}, \mathrm{Ca}, \mathrm{Fe}, \mathrm{K}, \mathrm{Mg}, \mathrm{P}, \mathrm{Si}$, and Ti. Both modifiers caused increments of sensitivities for all analytes in up to $665 \%\left(\mathrm{Na}_{2} \mathrm{CO}_{3}\right)$ and $583 \%\left(\mathrm{LiBO}_{2}\right)$ compared to the emission signals for analytes present in slurries prepared using samples ground without adding modifiers.

Keywords: mechanochemical synthesis, slurry, ICP OES, clays, refractory materials

\section{Introduction}

Analysis of inorganic materials using spectroanalytical techniques usually involves conversion of solid samples

\footnotetext{
* e-mail: djan@terra.com.br
}

in representative solutions. Depending on the characteristics of these materials, the digestion procedure can be tedious and can require the use of concentrated acids at high temperatures. ${ }^{1}$

When the sample to be analyzed is insoluble even in hot concentrated acids, a fusion method may be adopted. 
A mixture of the sample with a suitable flux in a fine-state division is heated at high temperatures in a furnace. Lithium metaborate or lithium tetraborate, sodium metaborate or sodium tetraborate, and sodium carbonate can be used as efficient fluxes. The time required in these procedures usually is around 4-8 h. . $^{2,3}$

Another procedure for analysis of inorganic materials is the direct analysis of slurries by inductively coupled plasma optical emission spectrometry (ICP OES). The slurry technique is based on the idea that a powdered sample of suitable small particle size held in an aqueous suspension of a certain percentage can be directly aspired into the plasma and analyzed. ${ }^{4,5}$

Taking into account that many types of samples such as silicate minerals, refractory compounds, and ceramics are not easily completely dissolved without contamination and losses of analytes, a number of methods have been developed to introduce slurries into plasmas. ${ }^{4-6}$

Some of the experimental factors that can influence the signal intensities for analytes in slurry nebulization are: the particle size distribution and atomization efficiency. ${ }^{4-6}$ In a review Ebdon et al. discussed the importance of particle size distribution measurements for the powder to be brought into suspension, the influence of the slurry concentration, and the calibration in slurry nebulization in ICP. ${ }^{7}$

Sanchez et al. described a practical method for the direct determination of $\mathrm{Al}, \mathrm{Ca}, \mathrm{Fe}, \mathrm{K}, \mathrm{Mg}, \mathrm{Mn}, \mathrm{Na}, \mathrm{Si}$, and $\mathrm{Ti}$ in slag samples by the introduction of suspensions into the ICP OES. The effect of particle size distribution on the atomization efficiency of these elements was evaluated. The results obtained shown that when particle sizes decreased, the intensities of emission signals increased around 20-fold for all elements. ${ }^{8}$

As it can be seen above is necessary to place under control a series of parameters, and in general the particle size is the most important. A wide range of grinding techniques and materials have been used to reduce the particle size in slurry preparation before ICP analysis. ${ }^{5,7}$

Atomization efficiency in the plasma is biased towards small particles and mean grain size of $<5-10 \mu \mathrm{m}$ is essential to ensure that the slurry has similar transport properties to an aqueous solution. ${ }^{9}$

The grinding time required depends on the type of mill, the intensity of grinding, the ball-to-powder ratio, and the temperature of grinding. The grinding time has to be decided for each combination of the above parameters and for a particular sample material. However, it should be pointed out that the level of contamination increases if the powder is milled for a time interval longer than required. ${ }^{10}$
Suryanarayana discussed in a comprehensive review that some types of reactions can occur during the grinding step. ${ }^{10}$ In this process mechanical energy is converted to chemical energy and chemical reactions are promoted during the grinding. This has been referred to in the literature as mechanochemical synthesis or mechanosynthesis.

One example of these processes can be observed when calcium hydroxide, $\mathrm{Ca}(\mathrm{OH})_{2}$, phosphorous oxide, $\mathrm{P}_{2} \mathrm{O}_{5}$, and calcium fluoride, $\mathrm{CaF}_{2}$, powders (9:3:1 m:m:m) are milled in a planetary ball mill. According to X-ray diffraction measurements, carbonated fluorhydroxyapatite, $\mathrm{Ca}_{10}\left(\mathrm{PO}_{4}\right)_{1-\mathrm{y}}\left(\mathrm{CO}_{3}\right)_{\mathrm{y}}\left(\mathrm{PO}_{4}\right)_{5}(\mathrm{OH})_{2-2 \times 1}(\mathrm{~F})_{2 \times 1}$ was formed after $5 \mathrm{~h}$ of milling and carbonated fluoroapatite $\mathrm{Ca}_{2}\left(\mathrm{PO}_{4}\right)_{1-\mathrm{y}}$ $\left(\mathrm{CO}_{3}\right)_{\mathrm{y}}\left(\mathrm{PO}_{4}\right)_{5}(\mathrm{~F})_{2}$ was formed after $9 \mathrm{~h}$ of milling. The X-ray patterns of the sample aliquots removed during different times of grinding had shown a continuous conversion of the original compounds in the new ones. ${ }^{11}$

A characteristic feature of all solid-state reactions is that they involve the formation of new products compounds at the interfaces of the reactants. ${ }^{10}$ Mechanochemical reaction can provide the means to substantially increase reaction rates. This is because the repeated welding and fracturing of powder particles increases the area of contact between the reactant powder particles due to a reduction of particle sizes and allows fresh surfaces to come into contact repeatedly. This allows the reaction to proceed without the necessity of diffusion through the product layer. As a consequence, reactions that normally require high temperatures will occur at lower temperatures during mechanochemical reaction without any externally applied heat. In addition, the high defect densities induced by mechanochemical reactions accelerate the diffusion processes. Alternatively, the particle refinement and consequent reduction in diffusion distances (due to microstructural refinement) can at least reduce the reaction temperatures significantly, even if they do not occur at room temperature.

The mechanochemical synthesis process could be exploited to promote chemical modifications in inorganic materials during the grinding step normally employed for preparation of slurries. The common view considers the grinding as an effective process to decrease particle sizes. We propose here that the grinding step could also be seen as a stage to promote chemical reactions and generate new chemical compounds that could improve the efficiency of atomization of slurries in ICP OES.

The procedure here proposed was based on the grinding of clays and refractory materials with added chemical modifiers to promote the formation of new compounds by mechanochemical synthesis. The formation of new 
compounds was investigated using X-ray diffraction (XRD) and thermogravimetric analysis (TGA) and the effects of the chemical modifications on the intensities of emission signals for elements in slurries introduced in ICP OES with axial viewing were evaluated.

\section{Experimental}

\section{Instrumentation}

The effects of mechanical synthesis on the emission intensities of analytes were evaluated using a VISTA AX simultaneous ICP OES spectrometer with axial view configuration (Varian, Mulgrave, Australia). The sample introduction system consists of a V-groove nebulizer and a Sturman-Masters type spray chamber made of polytetrafluorethylene (PTFE). The operating parameters and the selected analytical lines are listed in Table 1.

Table 1. Instrumentation and operating conditions for ICP OES with axial viewing

\begin{tabular}{|c|c|c|}
\hline \multicolumn{3}{|l|}{ Operating parameters } \\
\hline RF generator $(\mathrm{MHz})$ & \multicolumn{2}{|l|}{40} \\
\hline Power $(\mathrm{kW})$ & \multicolumn{2}{|l|}{1.3} \\
\hline Plasma flow rate $\left(\mathrm{L} \min ^{-1}\right)$ & \multicolumn{2}{|l|}{15} \\
\hline Auxiliary flow rate $\left(\mathrm{L} \mathrm{min}^{-1}\right)$ & \multicolumn{2}{|l|}{1.5} \\
\hline Nebulizer flow rate $\left(\mathrm{L} \mathrm{min}^{-1}\right)$ & \multicolumn{2}{|l|}{0.7} \\
\hline Replicates & \multicolumn{2}{|l|}{3} \\
\hline Injector tube diameter $(\mathrm{mm})$ & \multicolumn{2}{|c|}{2.4} \\
\hline Spray Chamber & \multicolumn{2}{|c|}{ Sturman-Masters } \\
\hline Nebulizer & \multicolumn{2}{|c|}{ V-groove } \\
\hline \multirow[t]{8}{*}{ Emission lines (nm) } & Al I & 394.399 \\
\hline & Ca II & 422.673 \\
\hline & Fe I & 239.561 \\
\hline & K I & 766.480 \\
\hline & $\mathrm{Mg}$ II & 280.268 \\
\hline & P I & 213.618 \\
\hline & Si I & 288.158 \\
\hline & Ti II & 334.938 \\
\hline
\end{tabular}

The mechanochemical synthesis reactions were performed in a high impact ball mill (SPEX 8000 CertPrep, Metuchen, NJ, USA). All grinding procedures were carried out using a tungsten carbide recipient and 2 balls (e.d. $10 \mathrm{~mm}$ ).

$\mathrm{X}$-Ray diffraction spectra of clays and refractory materials were obtained using a Siemens (München, Germany) Model D500 equipped with an X-ray tube with copper target operated at $40 \mathrm{kV}$ and $40 \mathrm{~mA}$, a Ni filter, and the goniometer was set at $0.6^{\circ}(2 \theta)$.

An ultrasonic bath USC (UNIQUE model 1400, SP, Brazil) was used for particle desegregation of slurries, and a vortex mixing (Maxi Mix II, Thermolyne, USA) was used to ensure homogeneity of slurry samples before introduction into the ICP OES.
The thermal decomposition studies were performed over a temperature range of $20-1000{ }^{\circ} \mathrm{C}$ using a Simultaneous DSC-TGA (model SDT 2960, TA Instruments, USA) thermogravimetric analysis system under an air environment at a flow-rate of $0.1 \mathrm{~L} \mathrm{~min}^{-1}$ and a scan rate of $10{ }^{\circ} \mathrm{C} \mathrm{min}-1$.

Samples and reagents

All reagents employed were of analytical grade. Nitric acid (Merck, Darmstadt, Germany) was used for slurry preparation. The slurries were prepared with Milli-Q water (Millipore, Bedford, MA, USA). Mechanochemical synthesis reactions were carried out using two chemical modifiers: $\mathrm{LiBO}_{2}$ (Merck, Rio de Janeiro, RJ, Brazil) and $\mathrm{Na}_{2} \mathrm{CO}_{3}$ (Merck).

Clays (IPT-28, IPT-32, and IPT-42) and refractory certified reference materials (IPT-57 and IPT-63) prepared by the Instituto de Pesquisas Tecnológicas, São Paulo, SP, Brazil, were used in this work. The use of these materials will facilitate the evaluation of emission intensities for different analytes and did not imply that they will be employed for assessment of accuracy.

\section{Procedures}

Grinding step. Mechanochemical synthesis was utilised to synthesize new compounds in clays and refractory materials. In this study the effects caused by two chemical modifiers, $\mathrm{LiBO}_{2}$ and $\mathrm{Na}_{2} \mathrm{CO}_{3}$ both anidrous, were evaluated. These modifiers were chosen taking into account their conventional use as fluxes. A mass of $0.5 \mathrm{~g}$ of clays or refractory materials was mixed with $2.5 \mathrm{~g}$ of each modifier and ground for $0.5-3.0 \mathrm{~h}$ using a ball mill with a tungsten carbide grinding container. Two tungsten carbide balls were added to the container.

The effect of the grinding time was investigated by using these conditions and varying the grinding time in $0.5,1.0,1.5,2.0$, and $3.0 \mathrm{~h}$.

For a preliminary evaluation of particle size effects, ground samples were screened through a $37 \mu \mathrm{m}$ (400 mesh) Nylon sieve. Slurries were prepared using the sample fraction with particle sizes lower than $37 \mu \mathrm{m}$ and using the ground sample without any sieving. Each sample was dried at $105^{\circ} \mathrm{C}$ for $1 \mathrm{~h}$ after the grinding step.

Preparation of slurries. The ground and chemically modified clays and refractory materials were characterized by X-ray diffraction and thermal analysis.

These powders were also used for preparation of slurries by dispersing $0.12 \mathrm{~g}$ of sample in $100 \mathrm{ml}$ of $10 \% \mathrm{v} \mathrm{v}^{-1}$ $\mathrm{HNO}_{3}$ solution. Slurries were sonicated for $5 \mathrm{~min}$ before introducing them into the plasma. This procedure was 
based on a procedure developed by Silva et al. for analysis of clays. $^{12}$

Chemical modification effects were evaluated by changes in the emission intensities of $\mathrm{Al}, \mathrm{Ca}, \mathrm{Fe}, \mathrm{K}, \mathrm{Mg}, \mathrm{P}$, $\mathrm{Si}$, and Ti measured in an ICP OES with axial viewing.

Effect of masses of $\mathrm{LiBO}_{2}$ and $\mathrm{Na}_{2} \mathrm{CO}_{3}$ on emission intensities of analytes

It is well known that lithium and sodium, frequently called easily ionisable elements, cause appreciable effects on emission intensities of other analytes in ICP OES. ${ }^{7}$ Thus it is important to estimate these effects for a better evaluation of the emission intensities measured when introducing modified slurries. In this study the effects caused on emission intensities of analytes by gradual addition of increasing masses of $\mathrm{LiBO}_{2}$ and $\mathrm{Na}_{2} \mathrm{CO}_{3}$ in slurries prepared using $20 \mathrm{mg}$ of IPT-42 in $10 \% \mathrm{v} \mathrm{v}^{-1} \mathrm{HNO}_{3}$ were evaluated. The masses of $\mathrm{LiBO}_{2}$ or $\mathrm{Na}_{2} \mathrm{CO}_{3}$ added were 20, 40, 60, 80, and $100 \mathrm{mg}$. This latter mass was also added to slurries prepared from a modified IPT-42 material for comparison purposes.

\section{Results and Discussion}

\section{Effects of mechanical alloying on chemical composition}

The mechanochemical synthesis of new compounds in clays and refractory materials ground with either $\mathrm{Na}_{2} \mathrm{CO}_{3}$ or $\mathrm{LiBO}_{2}$ were characterised using XRD and TGA. All characterisation experiments were performed using samples ground for $2 \mathrm{~h}$ since this grinding time was established as the best one to increase emission intensities of analytes in ICP OES as it will be discussed later on.

The difractograms showed in Figure 1 demonstrated that the grinding step in the presence of both chemical modifiers was effective for generating new compounds. The difractogram for IPT-42 clay ground without modifier shows that quartz and kaolinite were present in the sample. On the other hand, when $\mathrm{LiBO}_{2}$ was added during the grinding step, cristobalite, ankelite, rutile, and lithium boron hydroxide were produced. The use of $\mathrm{Na}_{2} \mathrm{CO}_{3}$ during the grinding step led to the formation of thermonatrite, muscovite, rutile, and sodium hydrogen oxalate hydrate.

Compounds detected in other samples before and after modification are summarized in Table 2. As it can be seen, all materials produced new compounds when ground with a chemical modifier, indicating the occurrence of chemical reactions in solid phase. Additionally, it can also be seen that some original compounds remained even after grinding with the modifier because they are either present in high concentrations in the original sample or are chemically more stable.

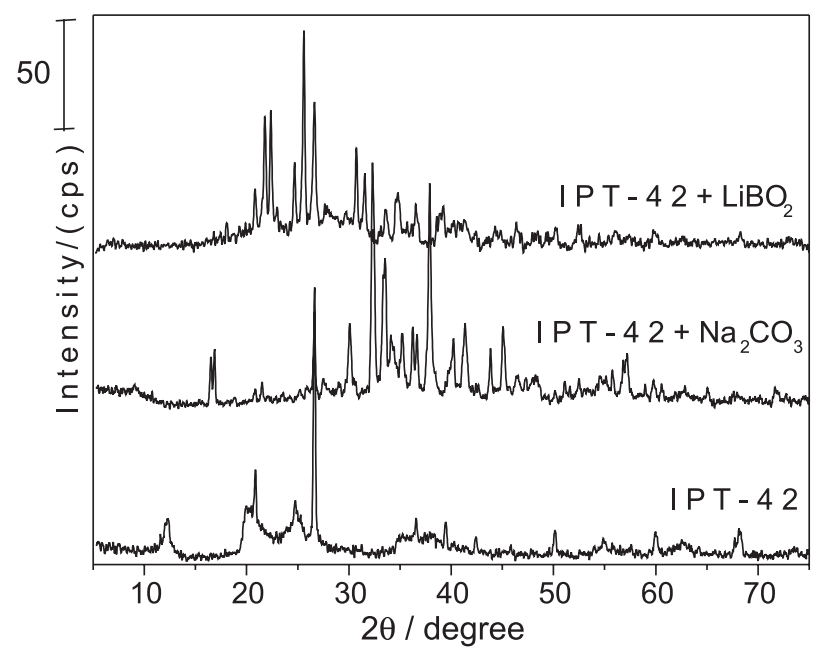

Figure 1. X-ray diffraction analysis of IPT-42 unmodified and modified with $\mathrm{LiBO}_{2}$ or $\mathrm{Na}_{2} \mathrm{CO}_{3}$.

Thermogravimetric analysis can be used to a preliminary evaluation of the thermal behavior of the new compounds generated in clays and refractory materials.

The TGA curves, under oxidant atmosphere, for one clay and one refractory material without modification and modified with $\mathrm{LiBO}_{2}$ are depicted in Figures 2 and 3. The TGA curves obtained for samples ground with or without adding this modifier showed appreciable differences of thermal stability. For comparison purposes the TGA curve for $\mathrm{LiBO}_{2}$ is also shown.

The ground and non-modified clay sample presented a loss of mass caused by thermal degradation around 500 and $600{ }^{\circ} \mathrm{C}$ (Figure 2). On the other hand, the loss of mass occurred between 200 and $350{ }^{\circ} \mathrm{C}$ for the clay sample ground after adding $\mathrm{LiBO}_{2}$. The residual mass at $1000{ }^{\circ} \mathrm{C}$

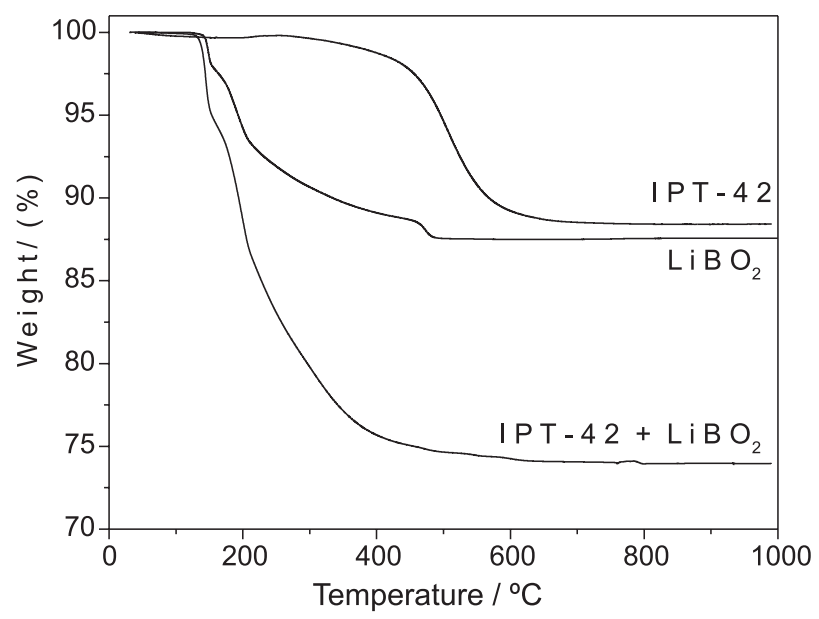

Figure 2. Thermogravimetric curves for $\mathrm{LiBO}_{2}$ and for IPT-42 ground without modifier and with $\mathrm{LiBO}_{2}$. 
Table 2. Compounds detected by X-ray diffraction analysis in samples ground with and without modifier

\begin{tabular}{|c|c|c|c|}
\hline Sample Material & Ground without modifier & Ground with $\mathrm{LiBO}_{2}$ & Ground with $\mathrm{Na}_{2} \mathrm{CO}_{3}$ \\
\hline Clay IPT-28 & Kaolinite & $\begin{array}{l}\text { Quartz } \\
\text { Lithium boron hydroxide } \\
\text { Diomignite }\end{array}$ & $\begin{array}{l}\text { Trona } \\
\text { Thermonatrite }\end{array}$ \\
\hline Clay IPT-32 & Kaolinite & $\begin{array}{l}\text { Kaolinite } \\
\text { Diomignite } \\
\text { Sassolite }\end{array}$ & $\begin{array}{l}\text { Trona } \\
\text { Thermonatrite } \\
\text { Quartz }\end{array}$ \\
\hline Clay IPT-42 & $\begin{array}{l}\text { Quartz } \\
\text { Kaolinite }\end{array}$ & $\begin{array}{l}\text { Cristobalite } \\
\text { Ankelite } \\
\text { Rutile } \\
\text { Lithium boron hydroxide } \\
\text { Quartz }\end{array}$ & $\begin{array}{l}\text { Thermonatrite } \\
\text { Muscovite } \\
\text { Rutile } \\
\text { Sodium hydrogen oxalate hydrate } \\
\text { Quartz }\end{array}$ \\
\hline Refractory material IPT-57 & $\begin{array}{l}\text { Mulite } \\
\text { Quartz } \\
\text { Corundum }\end{array}$ & $\begin{array}{l}\text { Quartz } \\
\text { Lithium boron hydroxide } \\
\text { Mulite } \\
\text { Rutile } \\
\text { Corundum }\end{array}$ & $\begin{array}{l}\text { Thermonatrite } \\
\text { Mulite } \\
\text { Quartz } \\
\text { Trona } \\
\text { Corundum } \\
\text { Natrite }\end{array}$ \\
\hline Refractory material IPT - 63 & $\begin{array}{l}\text { Cristobalite } \\
\text { Tridymite } \\
\text { Rutile }\end{array}$ & $\begin{array}{l}\text { Quartz } \\
\text { Cristobalite } \\
\text { Tridymite } \\
\text { Lithium aluminum silicate } \\
\beta \text {-Spumode }\end{array}$ & $\begin{array}{l}\text { Thermonatrite } \\
\text { Cristobalite } \\
\text { Tridymite }\end{array}$ \\
\hline
\end{tabular}

(74\%) for the modified clay is smaller than that obtained for the non-modified clay $(88 \%)$.

The TGA curve for the IPT-57 refractory material is shown in Figure 3. No stage of loss of mass due to thermal degradation was observed for the sample ground without adding a modifier. After grinding with $\mathrm{LiBO}_{2}$, this sample presented two stages of losses of mass. The first step occurred between 200 and $400{ }^{\circ} \mathrm{C}$, and the second stage of thermal degradation can be observed between 400 and $500{ }^{\circ} \mathrm{C}$. Above $600^{\circ} \mathrm{C}$ the percentage of solid residue $(75 \%)$ for the modified material is appreciably smaller than that observed for the sample ground without adding a modifier

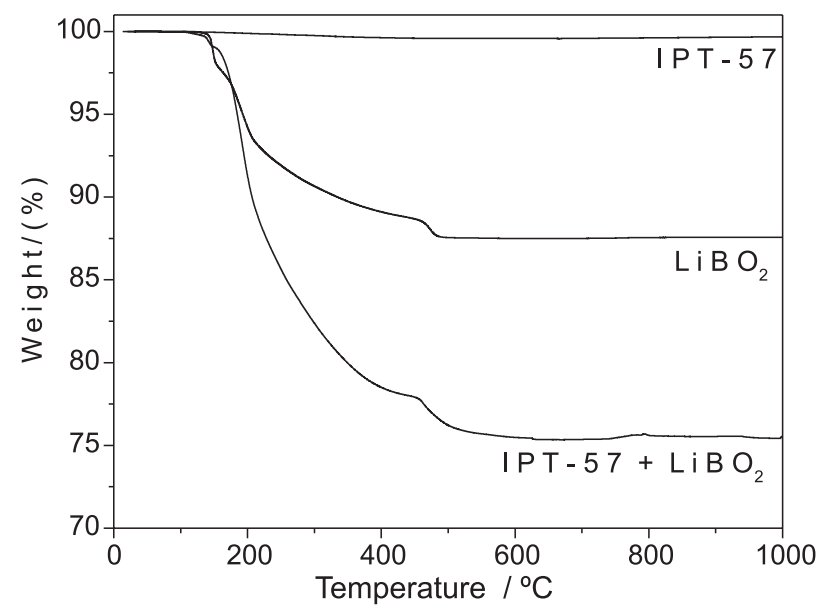

Figure 3. Thermogravimetric curves for $\mathrm{LiBO}_{2}$ and for IPT-57 ground without modifier and with $\mathrm{LiBO}_{2}$.
(99\%). These results also indicate that mechanochemical synthesis reactions can promote the formation of more volatile compounds.

\section{Effects of mechanochemical synthesis on emission intensities of analytes in ICP OES}

The effect of the grinding time on the emission intensities of $\mathrm{Al}, \mathrm{Ca}, \mathrm{Fe}, \mathrm{K}, \mathrm{Mg}, \mathrm{P}, \mathrm{Si}$, and $\mathrm{Ti}$ was investigated. Tables 3 and 4 show the percentage of variation in emission signal intensities for IPT-42 clay slurries modified with $\mathrm{LiBO}_{2}$ and $\mathrm{Na}_{2} \mathrm{CO}_{3}$, respectively. The emission intensities increased up to $718 \%$ depending on the analyte when the grinding time was $3 \mathrm{~h}$. Results obtained for slurries prepared after 2 or $3 \mathrm{~h}$ of grinding for almost of elements were similar, consequently all further experiments were carried out adopting $2 \mathrm{~h}$ of grinding.

As expected, chemical modification affected the emission intensities for $\mathrm{Al}, \mathrm{Ca}, \mathrm{Fe}, \mathrm{K}, \mathrm{Mg}, \mathrm{P}, \mathrm{Si}$, and Ti. Increments on emission intensities for slurries of IPT-42, a clay material, and of IPT-57, a refractory material, can be seen in Tables 5 and 6, respectively. Both chemical modifiers caused appreciable increment in emission intensities for most elements in both standard reference materials. Comparing the emission intensities for analytes in slurries prepared using samples ground with and without modifier, it was observed that for all analytes the emission intensities increased in the 140 to $665 \%$ range when 
$\mathrm{Na}_{2} \mathrm{CO}_{3}$ or in the 115 to $583 \%$ range when $\mathrm{LiBO}_{2}$ were added during the grinding step. This was particularly significant in the case of $\mathrm{Al}, \mathrm{Ti}$, and Si. Measurements of slurries prepared using IPT-42 sample modified during grinding led to enhancements of emission intensities of $155 \%\left(\mathrm{LiBO}_{2}\right)$ and $211 \%\left(\mathrm{Na}_{2} \mathrm{CO}_{3}\right)$ for $\mathrm{Al}, 583 \%\left(\mathrm{LiBO}_{2}\right)$ and $665 \%\left(\mathrm{Na}_{2} \mathrm{CO}_{3}\right)$ for $\mathrm{Ti}$, and $98 \%\left(\mathrm{LiBO}_{2}\right)$ and $140 \%$ $\left(\mathrm{Na}_{2} \mathrm{CO}_{3}\right)$ for $\mathrm{Si}$.

Table 3. Effect of the grinding time on percentage of increment of emission intensities of analytes for IPT-42 clay slurries modified with LiBO 2

\begin{tabular}{|c|c|c|c|c|c|c|c|c|c|c|}
\hline \multirow[b]{2}{*}{ Analyte } & \multicolumn{2}{|c|}{0.5} & \multicolumn{2}{|c|}{1.0} & \multicolumn{2}{|c|}{$\begin{array}{c}\text { time } / \mathrm{h} \\
1.5\end{array}$} & \multicolumn{2}{|c|}{2.0} & \multicolumn{2}{|c|}{3.0} \\
\hline & Mean & RSD & Mean & RSD & Mean & RSD & Mean & RSD & Mean & RSD \\
\hline Al & 131 & 1.3 & 146 & 0.9 & 156 & 1.3 & 160 & 1.8 & 163 & 1.9 \\
\hline $\mathrm{Ca}$ & 124 & 2.9 & 139 & 3.9 & 150 & 3.1 & 160 & 4.8 & 165 & 6.1 \\
\hline $\mathrm{Fe}$ & 135 & 4.7 & 153 & 3.5 & 157 & 4.2 & 170 & 4.1 & 178 & 5.9 \\
\hline $\mathrm{K}$ & 328 & 5.1 & 374 & 4.2 & 386 & 4.3 & 405 & 3.9 & 435 & 5.3 \\
\hline $\mathrm{Mg}$ & 123 & 1.3 & 134 & 2.1 & 142 & 2.4 & 150 & 1.9 & 162 & 2.1 \\
\hline $\mathrm{P}$ & 49.5 & 1.6 & 68.5 & 2.7 & 85.8 & 1.9 & 100 & 3.1 & 109 & 4.0 \\
\hline $\mathrm{Si}$ & 495 & 2.3 & 472 & 3.3 & 528 & 2.9 & 590 & 4.1 & 634 & 3.7 \\
\hline $\mathrm{Ti}$ & 131 & 5.9 & 146 & 4.3 & 156 & 4.5 & 160 & 5.7 & 163 & 6.7 \\
\hline
\end{tabular}

All values were based on 3 measurements and calculated by comparison with emission intensities obtained for a IPT-42 clay slurry ground without adding any modifier. RSD: relative standard deviation.

Table 4. Effect of the grinding time on percentage of increment of emission intensities of analytes for IPT-42 clay slurries modified with $\mathrm{Na}_{2} \mathrm{CO}_{3}$

\begin{tabular}{|c|c|c|c|c|c|c|c|c|c|c|}
\hline \multirow[b]{2}{*}{ Analyte } & \multicolumn{2}{|c|}{0.5} & \multicolumn{2}{|c|}{1.0} & \multicolumn{2}{|c|}{$\begin{array}{c}\text { time } / \mathrm{h} \\
1.5\end{array}$} & \multicolumn{2}{|c|}{2.0} & \multicolumn{2}{|c|}{3.0} \\
\hline & Mean & RSD & Mean & RSD & Mean & RSD & Mean & RSD & Mean & RSD \\
\hline $\mathrm{Al}$ & 187 & 2.3 & 187 & 1.4 & 207 & 2.9 & 210 & 2.1 & 210 & 1.8 \\
\hline $\mathrm{Ca}$ & 214 & 3.4 & 234 & 3.2 & 291 & 3.5 & 300 & 4.8 & 314 & 6.1 \\
\hline $\mathrm{Fe}$ & 195 & 4.4 & 182 & 4.7 & 221 & 5.2 & 240 & 6.1 & 249 & 6.5 \\
\hline K & 258 & 5.3 & 259 & 4.9 & 290 & 4.2 & 300 & 5.1 & 315 & 5.8 \\
\hline $\mathrm{Mg}$ & 188 & 1.7 & 181 & 2.2 & 215 & 2.4 & 230 & 1.9 & 238 & 2.1 \\
\hline $\mathrm{P}$ & 112 & 3.1 & 118 & 2.9 & 130 & 3.3 & 140 & 4.1 & 146 & 4.6 \\
\hline $\mathrm{Si}$ & 569 & 3.2 & 448 & 3.9 & 575 & 4.9 & 660 & 4.5 & 718 & 4.7 \\
\hline $\mathrm{Ti}$ & 187 & 5.3 & 187 & 4.9 & 207 & 5.5 & 210 & 6.7 & 210 & 7.1 \\
\hline
\end{tabular}

All values were based on 3 measurements and calculated by comparison with emission intensities obtained for a IPT-42 clay slurry ground without adding any modifier. RSD: relative standard deviation.

Table 5. Effect of chemical modification during grinding on emission intensities of analytes for slurries of IPT-42. All data are based on 3 measurements

\begin{tabular}{|c|c|c|c|c|c|c|c|c|c|}
\hline & & $\mathrm{Al}$ & $\mathrm{Ca}$ & $\mathrm{Fe}$ & $\mathrm{K}$ & $\mathrm{Mg}$ & $\mathrm{P}$ & $\mathrm{Si}$ & $\mathrm{Ti}$ \\
\hline \multirow{2}{*}{$\mathrm{IPT}-42+\mathrm{LiBO}_{2}$} & $\%$ & 155 & 156 & 168 & 405 & 147 & 115 & 98 & 583 \\
\hline & RSD & 0.8 & 2.9 & 5.6 & 7.0 & 2.2 & 0.1 & 3.0 & 17.0 \\
\hline \multirow{2}{*}{ IPT-42 $+\mathrm{Na}_{2} \mathrm{CO}_{3}$} & $\%$ & 211 & 297 & 235 & 603 & 227 & 172 & 140 & 665 \\
\hline & RSD & 0.9 & 9.5 & 3.9 & 1.3 & 0.6 & 3.4 & 2.3 & 6.8 \\
\hline
\end{tabular}

Table 6. Effect of chemical modification during grinding on emission intensities of analytes for slurries of IPT-57. All data are based on 3 measurements

\begin{tabular}{|c|c|c|c|c|c|c|c|c|c|}
\hline & & $\mathrm{Al}$ & $\mathrm{Ca}$ & $\mathrm{Fe}$ & $\mathrm{K}$ & $\mathrm{Mg}$ & $\mathrm{P}$ & $\mathrm{Si}$ & $\mathrm{Ti}$ \\
\hline \multirow{2}{*}{ IPT-57 + $\mathrm{LiBO}_{2}$} & $\%$ & 161 & 125 & 144 & 134 & 200 & 328 & 122 & 135 \\
\hline & RSD & 4.2 & 6.0 & 4.0 & 8.0 & 5.9 & 47.8 & 2.0 & 1.3 \\
\hline \multirow{2}{*}{ IPT-57 + $\mathrm{Na}_{2} \mathrm{CO}_{3}$} & $\%$ & 177 & 161 & 169 & 167 & 216 & 214 & 144 & 148 \\
\hline & RSD & 7.6 & 2.7 & 10.2 & 0.13 & 8.7 & 48.2 & 5.0 & 8.7 \\
\hline
\end{tabular}


It could be supposed that these increments on analyte emission intensities were caused by the presence of lithium and sodium in the slurries, since these cations are present in the modifiers.

An experiment was performed to evaluate this hypothesis by adding $\mathrm{LiBO}_{2}$ or $\mathrm{Na}_{2} \mathrm{CO}_{3}$ to slurries prepared using unmodified samples. The emission intensities obtained for $\mathrm{Al}, \mathrm{Fe}, \mathrm{Si}$, and $\mathrm{Ti}$ after addition of $\mathrm{LiBO}_{2}$ and $\mathrm{Na}_{2} \mathrm{CO}_{3}$ are shown in Figures 4 and 5, respectively.

As it can be seen the gradual increase of masses of $\mathrm{LiBO}_{2}$ or $\mathrm{Na}_{2} \mathrm{CO}_{3}$ in an unmodified clay sample, IPT-42, did not cause appreciable changes in the emission intensities of analytes. However, when each one of the modifiers was added before the grinding step, the emission intensities for all analytes were appreciably increased as already shown. Comparing the emission intensities for slurries prepared using chemically modified materials in an 1:5 clay:chemical modifier ratio and unmodified materials mixed with the same modifiers and ratios, the increase of emission intensities varied from 70 to $100 \%$ for all analytes. This is another indication of the occurrence of mechanochemical synthesis and implied that the observed gains in emission intensities are not caused by spectral interferences in ICP OES measurements.

Finally, it is well known that the particle size distribution of a slurry is the limiting factor controlling analytical performance. Considering atomizationexcitation processes in plasma, Raeymaekers et al. showed for refractory oxide slurries that the efficiency of atomization improves when working with slurries containing smaller particles. ${ }^{13}$ Ebdon and Collier studied particle size effects in kaolin slurries with a wide-range of particle sizes using ICP OES and they found that kaolin particles up to $8 \mu \mathrm{m}$ can be completely atomised in the $\mathrm{ICP}^{14}$

In the present study two different sizes fractions of a ground clay (IPT-42) were tested, one fraction without any separation of particle size after grinding and the other fraction with particle sizes smaller than $37 \mu \mathrm{m}$. Both fractions were chemically modified during the grinding step with $\mathrm{LiBO}_{2}$ and $\mathrm{Na}_{2} \mathrm{CO}_{3}$. Emission intensities for $\mathrm{Al}$, $\mathrm{Si}$, and $\mathrm{Ti}$ are shown in Figure 6. As it can be seen, after the chemical modification the difference in the intensity values between the two fractions is not significant. This is a preliminary indication that when using mechanochemical synthesis, the main factor controlling the efficiency of atomization is the thermal behavior of the particle that reached the plasma. However, these data are not conclusive because the distribution of particle sizes is not known, but it can also be mentioned that when a ground sample was sieved through the $37 \mu \mathrm{m}$ Nylon sieve,

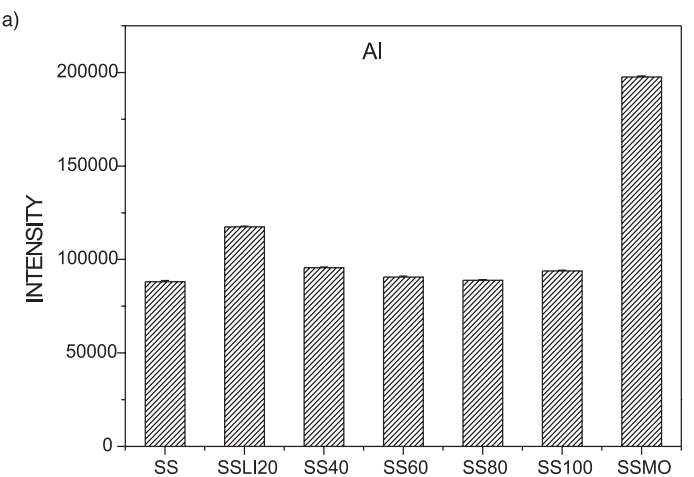

b)
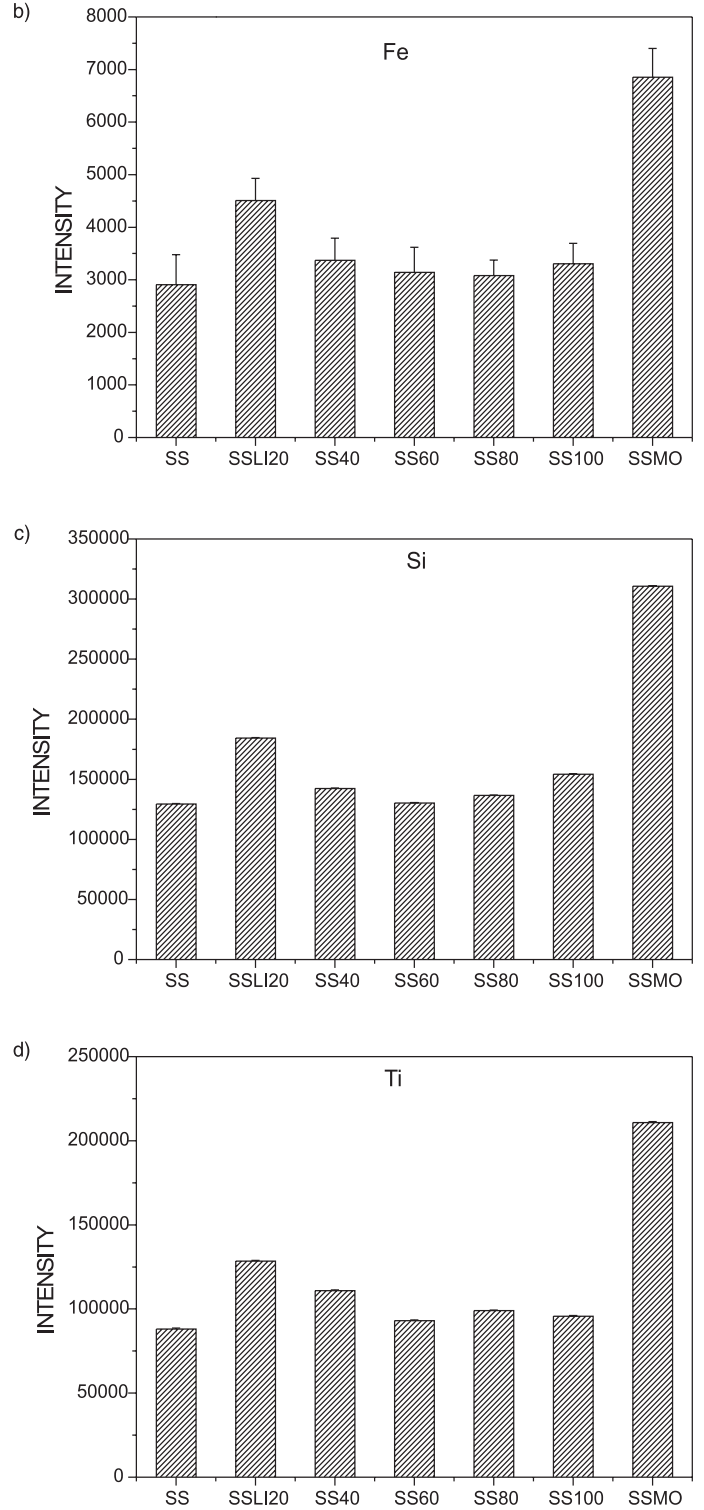

Figure 4. Emission intensities and relative standard deviations for (a) Al, (b) Fe, (c) Si, and (d) Ti from IPT-42 slurries, $20 \mathrm{mg} \mathrm{L}^{-1}$ in $10 \% \mathrm{v} \mathrm{v}^{-1} \mathrm{HNO}_{3}$ solution with gradual addition of $\mathrm{LiBO}_{2}$. SS without $\mathrm{LiBO}_{2}$ (sample:modifier ratio, 1:0 m:m), SS20 - with $20 \mathrm{mg}$ LiBO (1:1 m:m), SS40 - with $40 \mathrm{mg} \mathrm{LiBO}(1: 2 \mathrm{~m}: \mathrm{m})$, SS60 - with $60 \mathrm{mg} \mathrm{LiBO}$ (1:3 m:m), SS80 - with $80 \mathrm{mg} \mathrm{LiBO}$ (1:4 m:m), SS100 - with $100 \mathrm{mg} \mathrm{LiBO}$ (1:5 m:m), and SSMo - $120 \mathrm{mg}$ IPT-42 modified with $\mathrm{LiBO}_{2}$ in $10 \% \mathrm{v} \mathrm{v}^{-1} \mathrm{HNO}_{3}$ solution (1:5 m:m). 


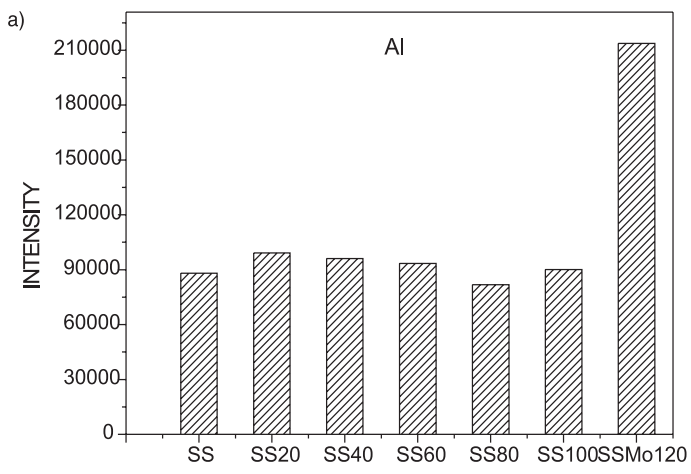

b)
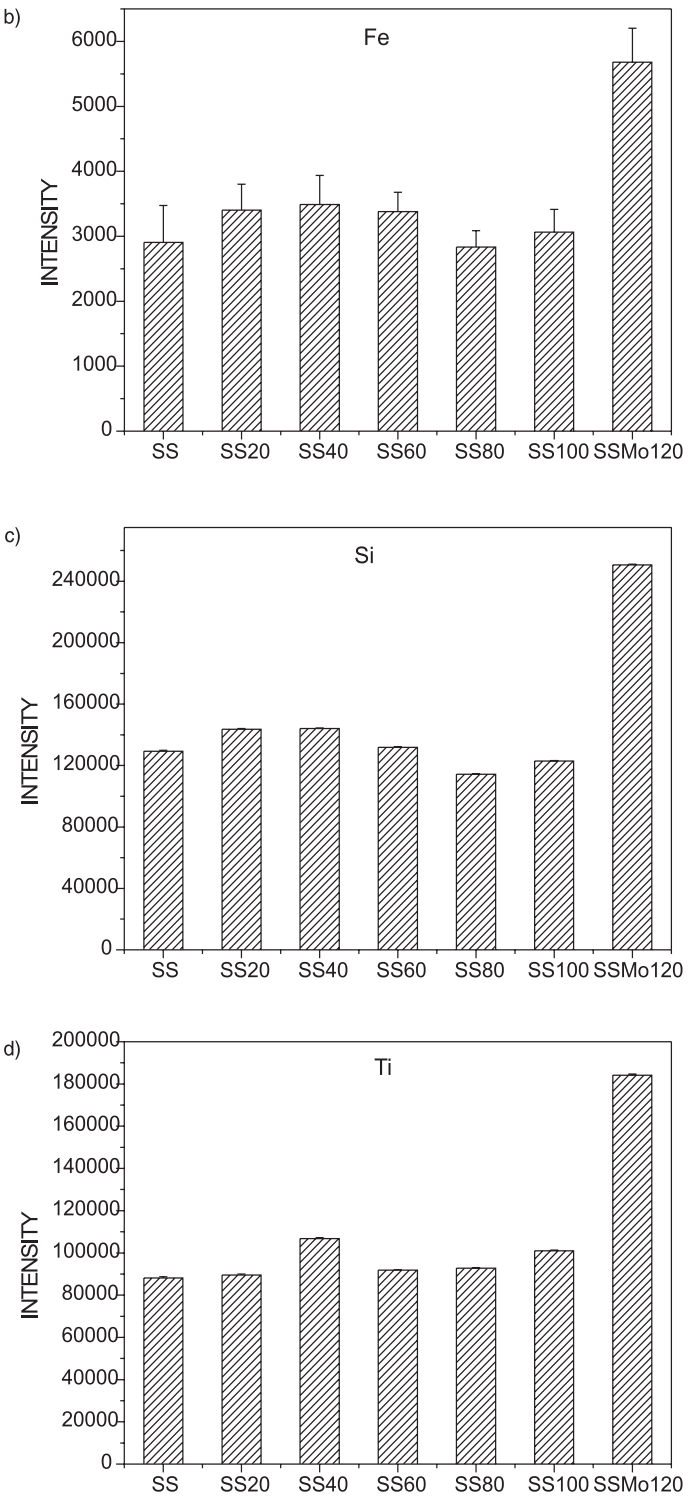

Figure 5. Emission intensities and relative standard deviations for (a) $\mathrm{Al}$, (b) Fe, (c) $\mathrm{Si}$, and (d) Ti from IPT-42 slurries, $20 \mathrm{mg} \mathrm{L}^{-1}$ in $10 \% \mathrm{v} \mathrm{v}^{-1} \mathrm{HNO}_{3}$ solution with gradual addition of $\mathrm{Na}_{2} \mathrm{CO}_{3}$. SS without $\mathrm{Na}_{2} \mathrm{CO}_{3}$ (sample:modifier ratio, 1:0 m:m), SS20 - with 20 mg Na $\mathrm{CO}_{3}(1: 1 \mathrm{~m}: \mathrm{m}), \mathrm{SS} 40$ - with $40 \mathrm{mg} \mathrm{Na} \mathrm{CO}_{3}(1: 2 \mathrm{~m}: \mathrm{m}), \mathrm{SS} 60$ - with $60 \mathrm{mg} \mathrm{Na} \mathrm{CO}_{3}(1: 3 \mathrm{~m}: \mathrm{m}), \mathrm{SS} 80$ - with $80 \mathrm{mg} \mathrm{Na}_{2} \mathrm{CO}_{3}(1: 4$ $\mathrm{m}: \mathrm{m}), \mathrm{SS} 100$ - with $100 \mathrm{mg} \mathrm{Na} \mathrm{CO}_{3}(1: 5 \mathrm{~m}: \mathrm{m})$, and SSMo - $120 \mathrm{mg}$ IPT-42 modified with $\mathrm{Na}_{2} \mathrm{CO}_{3}$ in $10 \% \mathrm{v} \mathrm{v} \mathrm{v}^{-1} \mathrm{HNO}_{3}$ solution $(1: 5 \mathrm{~m}: \mathrm{m})$. a percentage of $45-60 \%$ of the original powder did not pass through the sieve pores.
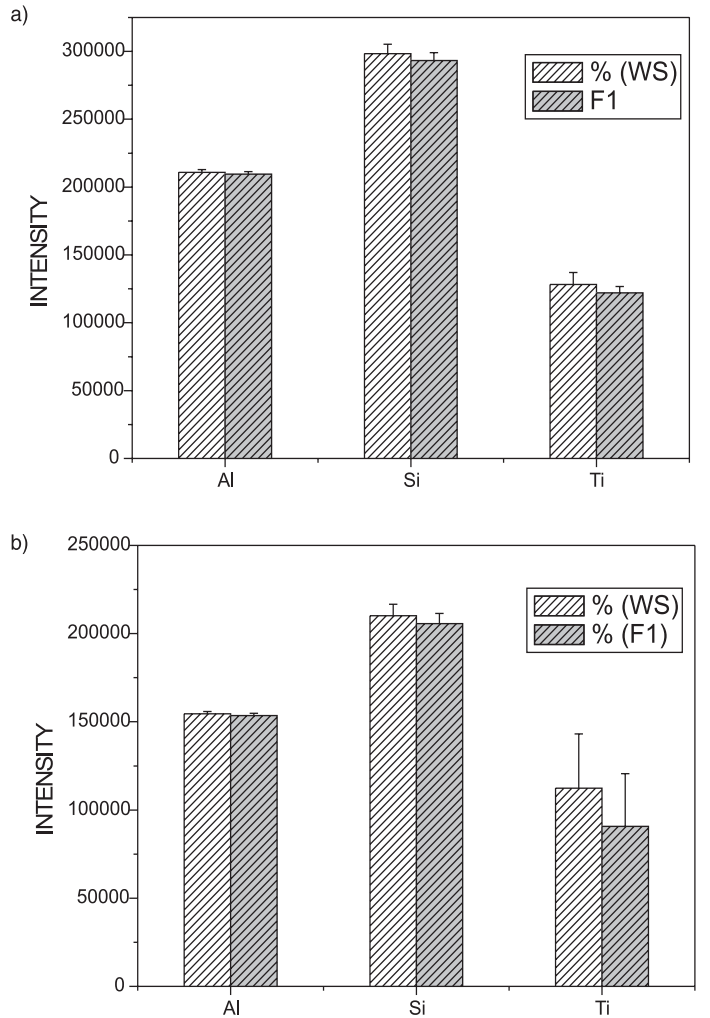

Figure 6. Emission intensities and relative standard deviations for $\mathrm{Al}, \mathrm{Si}$, and Ti $(\mathrm{n}=3)$. Slurries prepared from IPT-42 using (a) $\mathrm{Na}_{2} \mathrm{CO}_{3}$ or (b) $\mathrm{LiBO}_{2}$. WS - without separation of particle sizes and $\mathrm{F} 1$ - particles sizes lower than $37 \mu \mathrm{m}$.

\section{Conclusions}

It was demonstrated that mechanochemical synthesis processes were operative for generating new compounds when clays and refractory materials were ground in a high impact ball mill by adding either $\mathrm{LiBO}_{2}$ or $\mathrm{Na}_{2} \mathrm{CO}_{3}$ as chemical modifiers.

The formation of new compounds was confirmed by $\mathrm{X}$-ray diffraction and the higher volatilities of these when compared to samples ground without adding chemical modifiers were demonstrated by TGA measurements.

Slurries were prepared using these samples modified by grinding in the presence of chemical modifiers and the emission intensities of their constituents were measured by ICP OES with axial viewing. It was observed a significant increase of signals for all elements in all samples ground with either $\mathrm{LiBO}_{2}$ or $\mathrm{Na}_{2} \mathrm{CO}_{3}$.

Further developments will focus on the feasibility of this procedure for improving the calibration strategy when dealing with the direct introduction of slurries in ICP OES. 


\section{Acknowledgements}

The authors wish to express their appreciation to Fundação de Amparo à Pesquisa do Estado de São Paulo (São Paulo, SP, Brazil) for financial support of this research (FAPESP, Processes 02/04473-6 and 03/04502-9). We would like to thank M. Sc. Leandro Martins and Prof. Dr. Dilson Cardoso (Department of Chemical Engineering, Universidade Federal de São Carlos, São Carlos, SP, Brazil) for thermogravimetric analysis. J.A.N. and A.R.A.N. express their gratitude to Conselho Nacional de Desenvolvimento Científico e Tecnológico (CNPq, Brasília, DF, Brazil) for the researchships provided.

\section{References}

1. Ingle, J.D.; Crouch, S.R.; Spectrochemical Analysis, Prentice Hall: New Jersey, 1988.

2. Abollino, O.; Braglia, M.; Contardi, C.; Dai, G.; Mentasti, E.; Mosso, S.; Sarzanini, C.; Anal. Chim. Acta 1999, 383, 243.

3. Lau, O.; Lam, L.; Luk. S.; Talanta 2000, 51, 1009.

4. Borszéki, J.; Halmos, P.; Gegus, E.; Can. J. Anal. Sci. Spectrosc. 1997, 42, 165.
5. Jarvis, K.E.; Chem. Geol. 1992, 95, 73.

6. Nickel, H.; Broekaert, J.A.C.; Fresenius J. Anal. Chem. 1999, $363,145$.

7. Ebdon, L.; Foulkes, M.; Sutton, K.; J. Anal. At. Spectrom. 1997, 12, 213.

8. Sanchez, M.L.F.; Fairman, B.; Sanz-Medel, A.; J. Anal. At. Spectrom. 1991, 6, 397.

9. Totland, M.; Jarvis, I.; Jarvis, K.E.; Chem. Geol. 1993, 104, 175.

10. Suryanarayana, C.; Prog. Materials Sci. 2001, 46, 1.

11. Nikcevic, I.; Jokanovic, V.; Mitric, M.; Nedic, Z.; Makovec, D.; Uskokovic, D.; J. Solid State Chem. 2004, 177, 2565.

12. Silva, C. S.; Blanco, T.; Nóbrega, J.A.; Quím. Nova 2002, 25, 1194.

13. Raeymaekers, B.; Graule, T.; Broekaert, J.A.C.; Adams, F.; Tschöpel, P.; Spectrochim. Acta 1988, 43B, 923.

14. Ebdon, L.; Collier, A.R.; Spectrochim. Acta 1988, 43B, 355.

Received: December 2, 2004 Published on the web: April 6, 2005

FAPESP helped in meeting the publication costs of this article. 